\title{
PENGARUH MENGKONSUMSI PERMEN YANG MENGANDUNG ASESULFAM-K (SUGAR FREE) ATAU SUKROSE TERHADAP JUMLAH KOLONI BAKTERI Streptococcus mutans PADA SALIVA
}

\author{
Ardo Sabir \\ Bagian Ilmu Konservasi Gigi Fakultas Kedokteran Gigi, Universitas Hasanuddin, Makassar
}

\begin{abstract}
The purpose of the present study was to study the effect of consumed candy which contains acesulfame$\mathrm{K}$ (sugar free) or sucrose on the number of Streptococcus mutans colonies in saliva. Fifty volunteers that fulfilled the sampling criteria were randomly divided into two groups of equal size. The first group was instructed to consume candy containing acesulfame- $\mathrm{K}$ and the second group consumed candy containing sucrose. Before and after periods of 7, 14, 21 and 28 days, saliva of the volunteers was collected in sterile petri dishes, cultured in nutrient agar media and incubated for 24 hours at $37^{\circ} \mathrm{C}$. The number of $S$. mutans colonies was counted with a colony counter (CFU/ml). The data was statistically analyzed using KruskalWallis and Mann-Whitney tests ( $\alpha 95 \%$ ). The results showed that in the first group, the average number of $S$. mutans colonies decreased after consuming candy containing acesulfame- $\mathrm{K}$, although statistical analysis did not show significant difference $(\mathrm{p}>0.05)$. However, there was a significant difference $(\mathrm{p}<0.05)$ in the number of $S$. mutans colonies before and after consuming candy containing acesulfame-K for 28 days. In contrast, in the second group, after consuming candy containing sucrose, the average number of $S$. mutans colonies increased significantly $(p<0.05)$. There was also significant difference $(p<0.05)$ between before and after consuming sucrose candy for 21 and 28 days. Therefore the present results suggest that consuming candies containing acesulfame-K (sugar free) is useful to reduce the number of $S$. mutans colonies in saliva.
\end{abstract}

Key words: Acesulfame-K; sucrose; Streptococcus mutans; candy; saliva

\section{Pendahuluan}

Karies gigi terjadi pada semua penduduk di seluruh dunia tanpa memandang golongan usia, termasuk penduduk Indonesia. Berdasarkan hasil Survei Kesehatan Rumah Tangga (SKRT) ${ }^{1}$ tahun 2001 menunjukkan bahwa prevalensi karies pada kelompok usia 12 tahun adalah sebesar $44 \%$ dan merupakan karies primer yang sifatnya aktif. Pada kelompok usia kritis ini nilai indeks DMF-T yang diperoleh cukup baik yakni sebesar 1,1 atau hanya sedikit di atas target nasional yakni kurang dari 1 .
Walau demikian, hasil survei ini menunjukkan bahwa karies gigi masih merupakan masalah kesehatan gigi dan mulut yang dominan di negara kita.

Penyakit karies gigi sulit untuk dihilangkan oleh karena adanya pengaruh dari faktor eksternal seperti tingkat sosial, penghasilan, pendidikan, budaya, pola makan yang satu sama lainnya saling mempengaruhi. ${ }^{2,3}$. Faktor internal seperti bakteri yang bersifat kariogenik, saliva, karbohidrat yang dapat terfermentasi, dan kandungan fluor di dalam lingkungan mulut sangat berperan dalam proses

Alamat korespondensi: Ardo Sabir, Bagian Ilmu Konservasi Gigi, Fakultas Kedokteran Gigi, Universitas Hasanuddin, Jl. Kandea No.5 Makassar 90156. Tlp (0411)320022. e-mail: ardosabir@yahoo.com. 
terjadinya karies gigi oleh karena dapat mempengaruhi kolonisasi bakteri, proses demineralisasi serta remineralisasi gigi. ${ }^{3}$

Gula terutama jenis sukrose sudah lama dikenal dan telah digunakan secara luas dalam kehidupan sehari-hari baik di negara kita, hal ini disebabkan karena beberapa keunggulan yang dimiliki oleh sukrose antara lain rasanya yang manis, tekstur dan bentuknya. ${ }^{4}$ Hal tersebut merupakan faktor yang menyebabkan terjadinya peningkatan konsumsi sukrose di semua negara sebesar $\pm 2 \%$ setiap tahun pada dekade terakhir. Peningkatan ini lebih besar dari pertambahan jumlah penduduk dunia setiap tahunnya yakni sebesar $\pm 1,4 \%-1,6 \%{ }^{2,5}$

Terdapat hubungan antara konsumsi sukrose dengan aktivitas bakteri karies gigi. Semakin banyak jumlah sukrose yang dikonsumsi maka aktivitas bakteri karies makin tinggi pula yang pada akhirnya jumlah karies yang terjadi semakin bertambah. ${ }^{5} \mathrm{Hal}$ ini disebabkan oleh karena sukrose merupakan salah satu jenis karbohidrat utama yang dapat difermentasi dan bersifat kariogenik karena memiliki fungsi spesifik yaitu sebagai substrat bagi bakteri Streptococcus mutans dalam sintesis glukan ekstraseluler. ${ }^{6}$ Glukan ekstraseluler akan mengubah matriks plak gigi sehingga tingkat keasaman $(\mathrm{pH})$ dari lapisan plak gigi yang lebih dalam akan meningkat ${ }^{7,8}$. Akibatnya, plak gigi yang terbentuk akan lebih bersifat kariogenik karena terjadi peningkatan porositas dari matriks yang kaya akan glukan ${ }^{9,10}$. Oleh karena itu, berhenti atau membatasi konsumsi sukrose merupakan faktor yang sangat menentukan prevalensi karies gigi. ${ }^{5}$

Salahsatu cara efektif yang dianjurkan untuk mencegah meningkatnya jumlah bakteri S.mutans di dalam rongga mulut adalah dengan mengganti sukrose dengan bahan pemanis. Adapun definisi dari bahan pemanis adalah suatu bahan yang sangat manis atau pemanis yang tidak mengandung kalori dan terbuat dari bahan sintesis maupun bahan yang berasal dari alam, memiliki rasa manis melebihi rasa manis sukrose, tidak atau hanya sedikit menghasilkan energi, tidak memiliki bulk dan digunakan dalam jumlah sangat sedikit khususnya digunakan pada minuman atau dicampur dengan bahan pengganti sukrose pada bahan makanan dan minuman ringan. ${ }^{4}$

Telah banyak penelitian yang dilakukan baik pada hewan coba maupun pada manusia untuk mendapatkan jenis maupun konsentrasi yang tepat dari bahan pemanis ini untuk kepentingan kesehatan manusia ${ }^{11}$. Saat ini kita dapat menemukan berbagai jenis bahan pemanis yang dijual secara bebas di pasaran antara lain sakarin, siklamat, aspartam, dan asesulfam-K.

Asesulfam- $\mathrm{K}\left(\mathrm{C}_{4} \mathrm{H}_{5} \mathrm{NOS}\right)$, asesulfam kalium, atau garam kalium adalah bahan pemanis yang ditemukan pertama kali oleh Karl Clauss pada tahun 1967. Bahan pemanis ini mempunyai rasa manis 150-200 kali lebih manis dari sukrose, sifatnya sangat stabil, mampu beradaptasi pada temperatur tinggi (lebih dari $200^{\circ} \mathrm{C}$ ), larut dengan baik di dalam air, tidak menghasilkan kalori karena tidak dimetabolime oleh tubuh, diekskresikan melalui urin tanpa mengalami perubahan bentuk, dan relatif aman untuk dikonsumsi. ${ }^{12-15}$ Pada bulan Juli 1988, Food and Drug Administration (FDA) menyatakan bahwa asesulfam-K aman bagi kesehatan manusia dan dapat digunakan sebagai bahan pemanis tabletop ${ }^{16}$ dan sejak bulan Juli 1998 dinyatakan aman sebagai bahan pemanis pada minuman ringan ${ }^{17}$ sedangkan penggunaan asesulfam-K secara umum pada makanan dinyatakan aman oleh FDA pada bulan Desember 2003. ${ }^{18}$ The Joint Expert Committee on Food Additives (JECFA), suatu bahan ilmiah WHO dan FAO PBB menyimpulkan bahwa jumlah asupan asesulfam-K yang aman bagi kesehatan manusia untuk setiap hari (Acceptable Daily Intake [ADI]) adalah $15 \mathrm{mg} / \mathrm{kg} \mathrm{BB} /$ hari $^{19,20}$. Lamanya pernyataan yang dikeluarkan oleh FDA terhadap keamanan dari asesulfam- $\mathrm{K}$ terhadap kesehatan manusia disebabkan karena pada awal asesulfam- $\mathrm{K}$ diperkenalkan di masyarakat, dilaporkan kemungkinan asesulfam-K bersifat karsinogenik, menyebabkan gangguan tidur, disfungsi seksual, penyakit lupus, dan diabetes mellitus. Hasil dari sekitar 100 penelitian selama 15 tahun terhadap bahan pemanis ini tidak mendapatkan kemungkinan tersebut. ${ }^{14,16,21,22}$

Akhir-akhir ini telah beredar di pasaran permen yang menggunakan asesulfam- $\mathrm{K}$ sebagai bahan pemanis untuk menggantikan sukrose. Hingga saat ini hubungan antara bahan pemanis asesulfam- $\mathrm{K}$ pada permen (sugar free) dengan karies gigi belum pernah dilakukan. Oleh karena itu tujuan penelitian ini adalah untuk mengetahui pengaruh mengkonsumsi permen yang mengandung asesulfam- $\mathrm{K}$ (sugar free) atau sukrose terhadap jumlah koloni bakteri S.mutans pada saliva. Apabila dengan mengkonsumsi permen yang mengandung asesulfam-K (sugar free) terbukti mampu menurunkan jumlah koloni S.mutans pada saliva maka diharapkan dapat menjadi permen yang dipilih oleh masyarakat untuk mencegah terjadinya karies gigi. 


\section{Bahan dan Cara Kerja}

Jenis penelitian ini adalah penelitian laboratorium, dengan menggunakan permen yang mengandung asesulfam-K (sugar free) (Fox sugar free $e^{\circledast}$, PT Nestlé, Tangerang, Indonesia, kadaluarsa April 2007) dan permen yang mengandung sukrose (Fox ${ }^{\circledR}$, PT Nestlé, Tangerang, Indonesia, kadaluarsa April 2007) sebagai kontrol. Bahan pemeriksaan adalah koloni bakteri S.mutans berasal dari saliva sukarelawan. Media kultur bakteri S.mutans, digunakan media kultur nutrient agar (NA) yang komposisinya terdiri atas ekstrak ragi $3 \mathrm{~g}$, pepton 5 $\mathrm{g}$, agar $15 \mathrm{~g}$, dan aquades $1000 \mathrm{ml}$ dibuat sebanyak $250 \mathrm{ml}$ pada labu Erlenmeyer.

Pada penelitian ini sebanyak 40 mahasiswa Fakultas Kedokteran Gigi Universitas Hasanuddin Makassar yang memenuhi kriteria dipilih sebagai sampel. Kriteria sampel, yaitu laki-laki, berusia 1823 tahun, memiliki jumlah gigi minimal 28 gigi yang erupsi sempurna, bebas karies, kebersihan mulut baik, tidak mengalami kelainan jaringan periodontal, tidak sedang mengkonsumsi obat-obatan antibiotik/obat sistemik dan/atau memakai piranti ortodontik. Penelitian diawali dengan pengisian dan penandatanganan informed consent oleh sukarelawan sebagai tanda persetujuan. Sukarelawan dibagi menjadi 2 kelompok secara random sama banyak (tiap kelompok 20 sukarelawan). Kelompok I (Kelompok perlakuan) mengkonsumsi permen yang mengandung asesulfam-K (sugar free) sedangkan Kelompok II (Kelompok kontrol) mengkonsumsi permen yang mengandung sukrose.

Metode pengumpulan saliva pada penelitian ini menggunakan spitting method, ${ }^{23}$ sebelum mengkonsumsi permen, sukarelawan diminta untuk mengunyah paraffin steril selama 30 detik, kemudian salivanya ditampung pada pot yang telah disediakan. Terhadap kelompok I, sukarelawan diinstruksikan untuk mengkonsumsi permen yang mengandung asesulfam-K (sugar free) sebanyak 3 butir sehari selama 28 hari begitu pula halnya dengan yang mengkonsumsi permen sukrose (Kelompok II). Pada hari ke-7, 14, 21 dan hari ke-28 setelah mengkonsumsi permen, sukarelawan kembali diminta mengunyah paraffin steril selama 30 detik dan saliva ditampung dalam pot steril sebagai sampel.

Saliva sukarelawan sebelum dan setelah mengkonsumsi permen yang mengandung asesulfam-K (sugar free) maupun yang mengkonsumsi permen yang mengandung sukrose masing-masing $0,5 \mathrm{ml}$ dimasukkan ke dalam tabung berisi $4,5 \mathrm{ml}$ larutan salin steril, kemudian dilakukan deret pengenceran sampai 1000 kali. Dari saliva yang telah diencerkan sampai $1000 \mathrm{kali}$, diambil $0,5 \mathrm{ml}$ kemudian dibiakkan pada cawan petri yang berisi media kultur NA. Selanjutnya cawan petri diinkubasi selama 24 jam pada temperatur $37^{\circ} \mathrm{C}$.

Setelah masa inkubasi, dilakukan penghitungan jumlah CFU (Colony Forming Units) dari bakteri S.mutans menggunakan colony counter dan hasilnya ditabulasi serta dianalisis. Data yang diperoleh dianalisis secara statistik dengan $\alpha 95 \%$.

\section{Hasil}

Rerata dan simpang baku jumlah CFU bakteri S.mutans pada saliva dari kedua kelompok dapat dilihat pada tabel 1 berikut ini.

Berdasarkan Tabel 1, terlihat bahwa pada kelompok I terjadi penurunan rerata jumlah CFU bakteri S.mutans pada salivanya setelah mengkonsumsi permen yang mengan- dung asesulfam-K (sugar free). Selain itu terlihat pula bahwa pada kelompok I, semakin lama mengkonsumsi permen yang mengandung asesulfam-K (sugar free) maka jumlah CFU bakteri S.mutans pada saliva semakin berkurang pula. Hasil ini berlawanan dengan kelompok II yang pada kelompok ini terjadi peningkatan rerata jumlah CFU bakteri S.mutans setelah mengkonsumsi permen yang mengandung sukrose dan semakin lama mengkonsumsi maka semakin meningkat pula rerata jumlah CFU bakteri S.mutans pada saliva.

Tabel 1. Rerata dan simpang baku jumlah CFU S.mutans pada saliva dari setiap kelompok

\begin{tabular}{ccccc}
\hline $\begin{array}{c}\text { Lama } \\
\text { perla- } \\
\text { kuan } \\
\text { (hari) }\end{array}$ & \multicolumn{2}{c}{ Kelompok I (asesulfam- } & \multicolumn{2}{c}{ Kelompok II (sukrose) } \\
\hline 0 & 57.120 & $27.356,169$ & 64.680 & K) \\
7 & 55.200 & $26.340,716$ & 71.360 & $32.901,216$ \\
14 & 52.960 & $26.036,001$ & 78.720 & $33.771,931$ \\
21 & 49.520 & $25.932,798$ & 87.720 & $34.791,666$ \\
28 & 44.720 & $25.730,203$ & 105.520 & $37.608,864$ \\
\hline Keterangan : X = rerata, SD = simpang baku.
\end{tabular}

Sebelum data yang diperoleh dianalisis maka terlebih dahulu dilakukan uji normalitas dan uji homogenitas varians dari data dengan menggunakan uji Kolmogorov-Smirnov, dan diperoleh nilai probabilitas $0,000(<0,05)$ artinya data tidak normal dan tidak homogen. Oleh karena itu data dianalisis dengan menggunakan uji Kruskall-Wallis dilanjutkan 
dengan uji Mann-Whitney yang hasilnya tampak pada Tabel 2 dan 3 .

Tabel 2. Hasil uji Kruskall-Wallis mengenai perbedaan jumlah CFU S.mutans pada saliva dari setiap kelompok

\begin{tabular}{lccccccc}
\hline & \multicolumn{4}{c}{ Mean Rank } & $\begin{array}{c}\text { Uji } \\
\text { Kruska }\end{array}$ & P \\
\cline { 2 - 7 } Kelompok & Ohari & 7 hari & $\begin{array}{c}14 \\
\text { hari }\end{array}$ & $\begin{array}{c}21 \\
\text { hari }\end{array}$ & $\begin{array}{c}28 \\
\text { hari }\end{array}$ & $\begin{array}{c}\text { ll- } \\
\text { Wallis }\end{array}$ \\
\hline $\begin{array}{l}\text { I (asesul- } \\
\text { fam-K) } \\
\text { II (sukroes) }\end{array}$ & 73,46 & 68,90 & 65,02 & 58,40 & 49,22 & 6,849 & 0,144 \\
\hline
\end{tabular}

Keterangan : * Signifikan pada $\mathrm{p}<0,05$.

Tabel 3. Hasil uji Mann-Whitney mengenai perbedaan jumlah CFU S.mutans antara ke-5 waktu lama konsumsi dari setiap kelompok

\begin{tabular}{ccccccccc}
\hline $\begin{array}{c}\text { Lama } \\
\text { Perla } \\
\text {-kuan } \\
\text { (hari) }\end{array}$ & \multicolumn{3}{c}{ Kelompok I (asesulfam-K) } & \multicolumn{5}{c}{ Kelompok II (sukrose) } \\
\cline { 2 - 9 } & 7 & 14 & 21 & 28 & 7 & 14 & 21 & 28 \\
\hline 0 & 0,594 & 0,393 & 0,140 & $0,027^{*}$ & 0,393 & 0,107 & $0,013^{*}$ & $0,000^{*}$ \\
7 & & 0,641 & 0,273 & 0,067 & & 0,304 & $0,048^{*}$ & $0,001^{*}$ \\
\hline
\end{tabular}

Keterangan : * Signifikan pada $\mathrm{p}<0,05$.

Hasil analisis statistik dengan uji KruskallWallis pada Tabel 2 menunjukkan bahwa pada kelompok I tidak terdapat perbedaan yang signifikan $(\mathrm{p}>0,05)$ jumlah CFU bakteri S.mutans pada saliva sebelum dan setelah mengkonsumsi permen yang mengandung asesulfam-K (sugar free), sebaliknya pada kelompok II terjadi perbedaan yang signifikan $(\mathrm{p}<0,05)$ jumlah CFU bakteri S.mutans pada saliva sebelum dan setelah mengkonsumsi permen yang mengandung sukrose.

Untuk mengetahui perbedaan antara sebelum mengkonsumsi permen dengan setiap waktu lama konsumsi permen dari setiap kelompok, dan antar waktu lama konsumsi dari setiap kelompok maka dilakukan uji Mann-Whitney yang hasilnya dapat dilihat pada Tabel 3 berikut ini.

Pada Tabel 3 tampak bahwa pada kelompok I, terdapat perbedaan yang signifikan $(p<0,05)$ jumlah CFU bakteri S.mutans pada saliva hanya terjadi antara sebelum mengkonsumsi dengan 28 hari setelah mengkonsumsi permen yang mengandung asesulfam-K (sugar free). Sementara pada kelompok II, perbedaan yang signifikan tersebut $(p<0,05)$ terjadi antara sebelum mengkonsumsi permen yang mengandung sukrose dengan 21 hari dan 28 hari setelah mengkonsumsi permen tersebut. Selain itu juga terdapat perbedaan yang signifikan $(p<0,05)$ antara 7 hari dengan 21 hari dan 28 hari serta antara
14 hari dengan 28 hari setelah mengkonsumsi permen yang mengandung sukrose.

\section{Pembahasan}

Karies gigi merupakan suatu penyakit infeksi yang dapat menular dan terutama mengenai jaringan keras gigi, sehingga terjadi kerusakan jaringan keras setempat. Proses terjadinya kerusakan jaringan keras gigi melalui suatu reaksi kimiawi oleh bakteri, dimulai dengan proses kerusakan pada bagian anorganik, kemudian berlanjut pada bagian organik. ${ }^{24}$

Bakteri berperan penting pada proses terjadinya karies gigi karena tanpa adanya bakteri maka karies gigi tidak dapat terjadi. Terdapat berbagai macam spesies bakteri yang berkoloni di dalam rongga mulut. Salahsatu spesies bakteri yang dominan dalam rongga mulut adalah bakteri S.mutans. Jenis bakteri ini diketahui merupakan bakteri penyebab utama terjadinya karies gigi. ${ }^{25}$ Telah banyak penelitian yang membuktikan adanya hubungan yang erat antara jumlah bakteri S.mutans pada saliva dengan prevalensi karies gigi, ${ }^{24}$ hal ini disebabkan karena karakteristik dari bakteri S.mutans ${ }^{26}$ yaitu mampu mensintesis polisakarida ekstraseluler glukan ikatan $\alpha$ (1-3) yang tidak larut dari sukrose, mampu menghasilkan asam laktat melalui proses homofermentasi, dan lebih bersifat asidogenik dibanding spesies Streptococcus lainnya.

Sukrose adalah salah satu jenis karbohidrat yang dapat difermentasi oleh bakteri S.mutans menjadi asam. Asam ini selanjutnya akan mengiritasi dan menyebabkan terjadinya proses demineralisasi permukaan email gigi yang merupakan awal terjadinya karies gigi, sehingga untuk mencegah terjadinya karies gigi maka sedapat mungkin harus menghindar dari asupan sukrose. ${ }^{10,24}$ Oleh karena itu perlu mengganti sukrose dengan mencari bahan pemanis alternatif yang aman bagi kesehatan khususnya kesehatan gigi.

Asesulfam-K adalah salah satu jenis pemanis yang dapat kita temukan dan dijual secara bebas di pasaran dan telah dinyatakan aman oleh FDA untuk digunakan pada makanan ${ }^{18}$. Bahan pemanis ini dapat dikatakan bersifat non-kariogenik oleh karena bila bahan pemanis ini digunakan bersama-sama dengan siklamat dan sakarin maka dapat menghambat produksi asam yang dihasilkan oleh bakteri., ${ }^{41}$

Dari hasil penelitian ini terlihat bahwa pada kelompok I, semakin lama sukarelawan mengkonsumsi permen yang mengandung asesulfam-K (sugar 
free) maka rerata jumlah CFU bakteri $S$. mutans pada saliva semakin berkurang (Tabel 1), walaupun secara statistik tidak signifikan $(\mathrm{p}>0,05)$ (Tabel 2), terdapat perbedaan yang signifikan $(p<0,05)$ berkurangnya jumlah CFU bakteri S.mutans setelah mengkonsumsi permen yang mengandung asesulfam-K selama 28 hari dibanding sebelum mengkonsumsi (Tabel 3).

Penelitian mengenai pengaruh asesulfam- $\mathrm{K}$ terhadap karies hingga saat ini relatif masih sedikit sehingga mekanisme antikaries dari asesulfam-K masih belum jelas, walaupun beberapa hipotesis telah diajukan. Suatu penelitian secara in vitro melaporkan bahwa penambahan asesulfam-K pada media kultur bakteri S.mutans akan merubah arah gradien asam laktat dari arah dalam ke luar sel bakteri menjadi sebaliknya (dari luar ke dalam sel) sehingga energi yang dihasilkan tidak cukup untuk terjadinya glikolisis yang pada akhirnya mengakibatkan terhambatnya pertukaran asam laktat di dalam sel bakteri S.mutans. ${ }^{27}$ Sementara penelitian oleh Park dkk ${ }^{28}$ membuktikan bahwa berkumur dengan obat kumur yang mengandung asesulfam- $\mathrm{K}$ menyebabkan $\mathrm{pH}$ plak bersifat non-asidogenik. Hal ini mungkin disebabkan karena asesulfam-K berperan pada sistem transport glukosa yaitu dengan menghambat fermentasi glukosa pada sitomembran bakteri. $^{29}$ Pendapat yang berbeda diajukan oleh Linke $^{30}$ yang melakukan penelitian secara in vitro dan mendapatkan bahwa penambahan asesulfam-K sebanyak 2-20 $\mathrm{mg} / \mathrm{ml}$ pada media biakan akan menyebabkan berkurangnya pertumbuhan (daya adesi dan kemampuan koloni) bakteri S.mutans pada permukaan halus. Pada kelompok II terjadi peningkatan jumlah rerata CFU bakteri S.mutans pada saliva sukarelawan seiring dengan semakin lamanya waktu mengkonsumsi permen yang mengandung sukrose (Tabel 1), dan didukung oleh hasil analisis statistik menunjukkan hasil yang signifikan $(p<0,05)$ (Tabel 2). Selain itu, juga terdapat perbedaan yang signifikan $(<0,05)$ peningkatan jumlah CFU bakteri S.mutans setelah mengkonsumsi permen yang mengandung sukrose selama 21 dan 28 hari dibanding sebelum mengkonsumsi (Tabel 3).

Hasil ini jelas menunjukkan bahwa pemakaian sukrose akan meningkatkan jumlah CFU bakteri S.mutans. Hal ini disebabkan karena sukrose merupakan salahsatu jenis karbohidrat utama yang dapat difermentasi sehingga asam laktat pada saliva menjadi meningkat dan juga merupakan substrat bagi bakteri S.mutans dalam sintesis glukan ekstraseluler. ${ }^{6}$

\section{Kesimpulan dan Saran}

Dari hasil penelitian ini dapat disimpulkan bahwa terdapat penurunan yang signifikan $(p<0,05)$ jumlah CFU bakteri S.mutans pada saliva setelah mengkonsumsi permen yang mengandung asesulfam-K selama 28 hari. Sebaliknya, meng-konsumsi permen yang mengandung sukrose selama 21 dan 28 hari menyebabkan terjadinya peningkatan jumlah CFU bakteri S.mutans pada saliva secara signifikan $(p<0,05)$. Oleh karena itu, diharapkan bahwa tindakan mengkonsumsi permen yang mengandung asesulfam-K (sugar free) secara teratur dapat menjadi salahsatu cara yang dipilih oleh masyarakat untuk mencegah terjadinya karies gigi karena mampu mengurangi jumlah bakteri S.mutans pada saliva.

\section{Daftar Acuan}

1. Tim Surkesnas. Laporan SKRT 2001: Studi Morbiditas dan Disabilitas. Jakarta: Badan Penelitian dan Pengembangan Kesehatan Departemen Kesehatan, 2002.

2. Ismail AI, Tanzer JM, Dingle JL. Current Trends of Sugar Consumption in Developing Societies. Community Dent Oral Epidemiol 1997; 25: 438-43.

3. Fajerskov O. Concepts of Dental Caries and Their Consequences for Understanding the Disease. Community Dent Oral Epidemiol 1997; 25: 5-12.

4. Imfeld T. Efficacy of Sweeteners and Sugar Substitutes in Caries Prevention. Caries Res 1993; 27 (suppl 1): 50-5.

5. Burt BA. Relative Consumption of Sucrose and Other Sugars: Has It Been a Factor in Reduced Caries Experience? Caries Res 1993; 27 (suppl 1): 56-63.

6. Cury JA, Rebello MAB, Cury AADB. In situ Relationship between Sucrose Exposure and the Composition of Dental Plaque. Caries Res 1997; 31: 356-60.

7. Fu J, Zero DT, Anne KM, Dass A. Effect of Plaque Thickness on Glucose Retention and Acid Production (abstract 1815). J Dent Res 1991; 70 (special issue): 493.

8. Zero DT, Fu J, Anne KM, Cassata S, Mc Cormack SM, Gwinner LM. An Improved Intra-oral Enamel Demineralization Test Model for the Study of Dental Caries. J Dent Res 1992; 71 (special issue): 871-8.

9. Dibdin GH, Shellis RP. Physical and Biochemical Studies of Streptococcus mutans Sediments Suggest New Factor Linking with Cariogenicity of Plaque with Its Extracellular Polysaccharide Content. J Dent Res 1988; 67: 890-5. 
10. Van Houte J. Role of Microorganisms in Caries Etiology. J Dent Res 1994; 73: 672-81.

11. Sabir A. Peranan Bahan Pemanis dan Bahan Pengganti Gula dalam Mencegah Karies Gigi. Maj Ked Gigi (Edisi khusus TIMNAS II) 2001; 34(3a): 291-7.

12. Non-Caloric. Diakses dari: http://home.comcast. net/bkrentzman/nutrition/glossary.nutrition.html, Diakses tanggal 10 Desember 2006.

13. Anonymous. Acesulfame K Improves Dairy Foods High-Intensity Sweetener Blends Enhance Frozen Dairy Formulations. Dairy Foods 1997; 98 (10): 50.

14. Acesulfame-K. Diakses dari: http://www.elmhurst. edu/chm/vchembook/549.Acesulfame.html.7k, Diakses tanggal 5 Februari 2006.

15. Wilson LA, Wilkinson $\mathrm{K}$, Crews HM, Davies AM, Dick CS, Dumsday VL. Urinary Monitoring of Saccharin and Acesulfame-K as Biomarkers of Exposure to These Additives. Food Add \& Contaminants 1999; 16(6): 227-38.

16. Acesulfame-K Toxicity Information Center. Diakses dari: http://www.Holisticmed.com/acek/-3k, Diakses tanggal 17 Desember 2006.

17. Warshaw HS. Low-Calorie Sweeteners: What's News, What's New. Diabetes Spectrum 1999; 12 (4): 250-2.

18. Anonymous. Artificial Sweeteners: No Calories Sweet!. FDA Consumer 2006; 40(4): 27-8.

19. Low-Caloric Sweeteners: Acesulfame Potassium. Diakses dari: http://www.caloriccontrol.org/ acesulfame.html.10k, diakses tanggal 17 Desember 2006.

20. Rubin KW. Where We Stand Today: Artificial Sweeteners. Foodservice Director 2003; 16(5): 48.
21. Nutrition; Artificial Sweeteners Pose Negligible Carcinogenic Risk. Diakses dari: http://proquest.umi.com/pqdweb? did $=766375341 \&$ si $d=1 \& F m t=3 \&$ client, diakses tanggal 21 Januari 2007.

22. Hull JS. The Danger of Artificial Sweeteners. Total Health 2005; 27(1): 30-2.

23. Mahvash N. Method for Collecting Saliva. In: Malamed D (ed). Saliva as a Diagnostic Fluid. New York: The New York Academy of Science. 1993:727.

24. Roberson TM, Lundeen TF. Cariology: the Lesion, Etiology, Prevention, and Control. In: Roberson TM, Heymann HO, Swift Jr EJ (eds). Sturdrvant's Art \& Science of Operative Dentistry. $4^{\text {th }}$ ed. St Louis: Mosby. 2002: 65-132.

25. Lavelle CLB. Applied Oral Physiology. $2^{\text {nd }}$ ed. London: Wright. 1988: 96-7.

26. Roeslan OB. Karakteristik Streptococcus mutans Penyebab Karies Gigi. MI.Kedokteran Gigi 1995; 2930(10): 112-5.

27. Ziesenitz SC, Siebert G. Uptake of Saccharin and Related Intense Sweeteners by Streptococcus mutans NCTC 10449. Z Ernahrungswiss 1988; 27(3): 15569.

28. Park KK, Schemehorn BR, Stookey GK, Butchko HH, Sanders PG. Acidogenicity of High-Intensity Sweeteners and Polyols. Am J Dent 1995; 8(1): 23-6.

29. Pfeffer M, Ziesenitz SC, Siebert G. Acesulfame-K, Cyclamate and Saccharin Inhibit the Anaerobic Fermentation of Glucose by Intestinal Bacteria. Z Ernahrungswiss 1985; 24(4): 231-5.

30. Linke HA. Adherence of Streptococcus mutans to Smooth Surfaces in the Presence of Artificial Sweeteners. Microbios 1983; 36(143): 41-5. 